\title{
Some Unusual Sask. Bird Records
}

\section{By Fred W. Lahrman, Saskatchewan Museum of Natural History}

The dry weather of this past spring has caused the rapid drying up of the flooded fields and sloughs near the city of Regina, causing large areas of mud flats to be exposed. This provides ideal feeding and resting conditions for shore birds which appeared in unusually large numbers during the spring migration period. Among these were the Dunlin (Erolia alpina) and the Buff-breasted Sandpiper (Tryngites subruficollis) which are rarely seen in this area.

On May 6, 1958, two Dunlins were observed by Dr. R. W. Nero and myself, one of which was collected. Two were again observed by Dr. G. F. Ledingham on May 10, and three on May 18 by $\mathrm{F}$. H. Brazier.

The Museum has one other Dunlin specimen, a female, taken June 8, 1914, at Churchill River by A. Buchanan. Other Museum records include a specimen taken Augusit 9, 1920, Lake Athabasca, U.S. Biological Survey party; three males seen May 23, 1931, Round Lake, Broadview, F. G. Bard: reported seen 1932, Wascana Lake, Regina, F. Bradshaw.

On May 28 twenty Buff-breasted Sandpipers were observed by Dr. R. W. Nero and F. H. Brazier, and on May 29 Dr. Nero and I saw 94, three of which were collecited. On May 31, four were seen. Other Museum records are: one male collected, August 26, 1921, Old Wives Lake, H. H. Mitchell; two males collected, August 27, 1921, Old Wives Lake, H. H. Mitchell; three taken at Old Wives Lake, May 23, 1922, by C. G. Harold; one female taken May 29, 1930, Unity, by R. D. Symons; 19 collected, May 23, 1932, Imperial Beach, Lasit Mountain Lake, George M. Sutton ;one reported to F. G. Bard June 2, 1937, caught by a dcg. Identified as a Buff-breasited and made into a situdy skin.

Two other observations are of interest. A Snow Bunting (Plectrophenax nivalis) was observed June 15 on the shore of a large marsh approximately 12 miles east of Simpson. Although it was easily recognized as a Snow Bunting, it was strangely different in appearance, being much darker on the head and back than any I have ever seen. I presume that it was a female since it was so dark, and that this is how they appear when they arrive on their breeding grounds, where this one certainly should have been at this date.

The other unusual bird was a Black Duck (Anas rubripes) seen June 16 in the Regina Waterfowl Park. This is the first one I have observed on the Wascana Marsh. Other Museum records are: a specimen taken Oct. 25 , 1917, Last Mountain Lake, R. Lloyd, Davidson: a specimen taken in the fall of 19i8, Last Mountain Lake; one taken, Nov. 20, 1923, J. A. M. Patrick, Yorkton; one seen Oct. 5, 1932, Regina, F. G. Bard; a pair seen May 4, 1935, south of Lumsden, F. G. Bard; a male taken, Oct. 24, 1935, Cymric, $K$. Ross of Regina; a male taken, Oct. 28, 1936, Penzance, M. F. Parrott, Regina; 4 observed summer, 1957, Old Wives Lake (F.W.L.).

\section{The Black Duck in Saskatchewan}

By Lucy H. Murray, Regina

The report of a Black Duck on the Wascana Marsh (June 16, 1958) after an absence of twenty years or more is interesting. It has appeared in Saskatchewan in-the past at intervals of abcut twenty years $(1917-18$; 1932$36 ; 1958)$. Only two regions have been favoured, Last Mountain Lake (into which the Wascana drains) and Yorkton. The one record from Yorkton (1923) is strengthened by a second report in 1945 that four black ducks were banded there by J. 'H. Wilson (C. S. Houston, Canadian Field Naturalist, Vol. 63, No. 6). Are these sporadic appearances in limited areas true of its appearance in other regions, such as Minnescta and Manitoba?

The Black Duck has over the last forty years gradually extended its range from eastern North America westward, in Canada, over Ontario and Manitoba, and is now straying 
into Saskatchewan (F. A. Urquhart, 1957, Some Faunal Changes in Ontario, p. 29). It remains, however, essentially an eastern duck, appearing in great numbers in the Maritimes and in the New England States. From 1952-56, counts made of it on its wintering grounds (roughly south of the S.t. Lawrence-Great Lakes waterway and east of the Mississippi) showed the average yearly pspulation to be approximately 678,000 , threefifths of which were concentrated in the Atlantic coastal states. Even though it has extended its range westward, it breeds in great numbers only east of $85^{\circ}$ longitude. (R. E. Stewart, 1958, Distribution of the Black Duck, pp. 4-5).

In Minnesota, Roberts observed that while it was considered only a straggler from 1896-1910, in 1936 it was to be seen in flocks of twenty to thirty. Nesting records frcm 1922-29 showed that it was breeding in the northern part of the state, from Lake Superior to the country between Rainy River and Red Lake. One record even showed it nesting as far west as Twin Lakes and as far south as Leech Lake.

A similar trend was evident in Manitoba. In 1904 George Atkinson, (Macoun's colleague in Portage la Prairie), from the five specimens of Black Duck which were taken on the marshes south of -Lake Manitoba and sent to him and from the many sight records of it there, believed that it was established in Manitoba (B. J. Hales, 1927, Prairie Birds). In 1909 Macoun stated that he had never seen it west of the Red River and in 1927 B. J. Hales reported that in his fifteen years of frequenting the marshes south of Lake Manitoba he had never seen a single specimen. He had to add, however, that one had been sent to him frcm Oak Lake in 1921. By 1937 Taverner, judging by the numerous records of this duck in Manitoba, concluded that it seemed to be increasing in numbers. During 194650 in a count of "the Delta bag," taken by hunters annually, the Black Duck was listed in the group of species which formed $1 \%$ of the total shot (L. K. Sowls, 1955, Prairie Ducks, p. 160). In 1955 H. A. Hochbaum writing of the feeding of the Mallards upcn the stubble on Delta Marsh added that a small number of
Black Ducks mixed with the Mallard followed a schedule similar to that o the Mallards (Travels and Tradition of Waterfowl, p. 75).

The reports of the Black Duck's er ratic wanderings also show a gener movement of it westward. L. L. Sny der, in Arctic Birds of Canada (1957) c:bserved that it was a stray in 193 cn Cape Dcrset, Baffin Island; 1937, on Beverley Lake; in 1950, Chesterfield Inlet; and in 1958, False River, Ungava Bay. Mowat an Lawrie in 1947-9 found it on th north-west end of Nueltin Lake, Keo watin, and one hundred mile's farthe north on Angikuni Lake. From it absence in the two hundred miles timberland south of Nueltin Lake Brochet, on Reindeer Lake, they de cided that the individuals seen mus have ccme from the south-east-th southern shores of the Hudson $\mathrm{Ba}$ where Manning, in 1948, had foun them in numbers and even to $b$ breeding. (Canadian. Field Naturalis Vol. 69, No. 3; National Museum Bul letin, No. 128). Another curiousl negative report was that of Godfre who working in the south-east corne of Manitoba in 1951 found the Blac Duck only at Seven Sisters Falls, nea Lac du Bonnet. This was in spite o the fact that it was then establishe on Delta Marsh further west.

For some time studies have bee carried out to explain the sporadi and erratic appearance of birds i certain areas. Scme ducks have beel found to be naturally pioneers. On western duck, the Gadwall, has beel reported on the Atlantic coast. Ar eastern example, of course, would b Black Duck now straying into Sask atchewan. The return of birds yea. after year to certain areas is base on tradition (H. A. Hochbaum, 1955 Travels and Traditions of Waterfow $\mathrm{Pt}$. III). Once this tradition is broker the species disappears from that area Scme of the causes of this may b the disappearance of marshland through drought, or artificial drain age, and the overshcoting of the loca birds. When the ranges of two bird overlap, as has happened to the Mal lard and Black Duck in the centra part of North America, one specie generally thrives more than the ather. (P. L. Errington, 1957, Of $M$ e and Marshes, p. 22).

Whatever may have been the rea 
sons for the erratic appearances of the Black Duck in Saskatchewan in the past, naturalists will welcome a chance to follow any new reports hoping now, in the light of recent research, to be able to discover some of the causes. Our hunters will welcome reports cf the Black Duck's return for it is considered, by some, to be the "wildest," the most sagacious and wary of ducks. Our bird watchers, anxious to add this eastern bird to their lists, will eagerly scan each flock of Mallards hoping to see some Black Ducks. Such identifications should not be difficult. It is a large brown duck, appearing black at a distance, and easily distinguished from our cther sooty-coloured ducks, the Scoters, by its light streaked neck and head, its mallard bill, and the silvery white lining of its wings.

\title{
American Avocets Nesting at Oak Lake, Manitoba
}

\author{
By David Hatch, Oak Lake, Man.
}

EDITOR'S NOTE: David Hatch, at sixteen years of age, is an ardent bird watcher, and we welcome his contribution to the regular columns of the Blue Jay. Another young contributor who is a very keen bindman is Bill Horseman, of Saltcoats. Two pictures of hawks that he took this year appear on page 114 .

Plum Creek was dredged three years ago but no dam was built on it until mid July of this year. Because of this and also because we have had a dry summer, the famed Oak Lake marshes have dried up to such an extent that acres and acres of bare mudflats exist. This has resulted in some rare birds moving into this area. One of these, the most striking shorebird I have ever seen, is the American Avocet.

Up to 1957 I had never seen American Avocets, but that year a pair nested in the Oak Lake Marsh. This was the only American Avocet record for Manitoba that year. Although Mr. Herman Battersby, my birding companion, and I did look thoroughly for the nest we couldn't find it. When we were looking for the nest the pair would fly around dive-bombing us iust as Tree Swallows do when you are close to their nest. They also used the broken-wing act of the Killdeer.

By the end of May, 1958, fourteen Avocets were in this area. On June 23 two nests were found on the bare mudflat; one was about ten yards from the nearest rushes, the other was about 100 yards. The nest was a slight depression in the mud lined with about thirty coarse rushes two to three inches in length. One contained four eggs, the other three young and one egg. The large, sharply-pointed, clay-coloured eggs are blotched with black and have the odd pale blue spot. They are larger than a Killdeer's egg, but smaller than a Mallard Duck's. Like the plover's eggs, they have all their small ends pointing inward in the nest.

The downy young are web-footed. They would run quickly to the water and swim away from us. They are slightly tinged with rust ard when they sat still on the mud they were perfectly camouflaged.

Mr. Eddy Giggens took about twenty feet of film and both $\mathrm{Mr}$. Battersby and I took pictures with our cameras.

It is to be hoped that these magnificent birds will thrive in this area and will increase in number across the continent.

\section{MAMMALS OF SASKATCHEWAN}

We are pleased to announce that Harvey Beck's bulletin on the mammals of Saskatchewan is now being printed. As soon as it comes from the printers the bulletin will be mailed to those who have already written for a copy. The price of the Mammals of Saskatchewan is fifty cents. Order from E. L. Fox, 1053 Gladmer Park, Regina. 